\title{
First report of surra (Trypanosoma evansi infection) in a Tunisian dog
}

\author{
Mohamed Ridha Rjeibi ${ }^{1}$, Taoufik Ben Hamida ${ }^{2}$, Zara Dalgatova ${ }^{2}$, Tarek Mahjoub ${ }^{1}$, Ahmed Rejeb ${ }^{3}$, \\ Walid Dridi ${ }^{2}$, and Mohamed Gharbi ${ }^{1}$,* \\ 1 Laboratoire de Parasitologie, Université de la Manouba, École Nationale de Médecine Vétérinaire de Sidi Thabet, \\ 2020 Sidi Thabet, Tunisia \\ 2 Laboratoire de Parasitologie, Institut de la Recherche Vétérinaire de Tunisie, 20 Rue de Jebel Lakdhar, La Rabta, 1006 Tunis, Tunisia \\ 3 Laboratoire d'Anatomie-Pathologique, Université de la Manouba, École Nationale de Médecine Vétérinaire de Sidi Thabet, \\ 2020 Sidi Thabet, Tunisia
}

Received 29 September 2014, Accepted 21 January 2015, Published online 6 February 2015

\begin{abstract}
Trypanosoma evansi, the agent of surra, is a salivarian trypanosome, originating from Africa. Surra is a major disease in camels, equines and dogs, in which it can often be fatal in the absence of treatment. Animals exhibit nonspecific clinical signs (anaemia, loss of weight and abortion). In the present survey, a blood sample was collected in Sousse (Central Tunisia) from a dog that presented clinical signs of trypanosomiasis. Giemsa-stained blood smears and PCR were performed. ITS1 sequences from blood had 99.8 and $99.5 \%$ homology with published T. evansi sequences from cattle and camels, respectively. To our knowledge, this is the first report of T. evansi in a Tunisian dog.
\end{abstract}

Key words: Surra, Dog, Trypanosoma evansi, Molecular identification, Tunisia.

Résumé - Premier cas de surra (infection par Trypanosoma evansi) chez un chien en Tunisie. Trypanosoma evansi, l'agent du surra, est un trypanosome salivaria d'origine africaine. Le surra est une maladie importante chez le dromadaire, les équidés et le chien, qui est souvent fatale en l'absence de traitement. L'animal présente des signes cliniques non spécifiques (anémie, perte de poids, avortement). Dans la présente étude, l'échantillon de sang a été prélevé à Sousse (centre de la Tunisie) d'un chien présentant des signes cliniques de trypanosomose. Des étalements de sang colorés au Giemsa et des PCR ont été réalisés. Les séquences ITS1 avaient 99,8 et 99,5\% d'homologie avec des séquences de T. evansi, respectivement de bovins et de dromadaires. A notre connaissance, ceci est la première mention de T. evansi chez un chien en Tunisie.

\section{Introduction}

Trypanosoma evansi is the most widely distributed pathogenic salivarian trypanosome in animals, it causes a significant disease called surra. Main vectors worldwide are tabanids and Stomoxys spp.; oral transmission has been reported in a very wide range of domestic and wild hosts. Since 2008, notification of surra became compulsory not only in horses, because it is now considered a multi-species disease by the World Animal Health Organization (OIE) [13, 15]. This parasite is widely distributed; it is present in North Africa, in the Middle East, Turkey, India, up to $53^{\circ}$ North in Russia, across all South-East Asia, down to Indonesia and the Philippines. This parasite was introduced into Latin America

\footnotetext{
*Corresponding author: gharbim2000@yahoo.fr
}

by the conquistadores [5]. Trypanosoma evansi has been reported in the Canary Islands (Spain) where it has been regularly observed since 1995 [8], and the Spanish mainland (Alicante Province) in a mixed camel and horse farms [16]. In France, a single outbreak occurred in camels imported from the Canary Islands [4]. In Africa, T. evansi is mainly a parasite of camels, which represents both the main host and reservoir. T. evansi can infect cattle (Bos taurus) [6], pigs (Sus scrofa), domestic sheep (Ovis aries) and goats (Capra hircus) [5]. It is considered as non-pathogenic for African buffalo (Syncerus caffer) [14] and is occasionally reported in horses, dogs and cats $[5,18]$. Since 2005, surra has been considered as zoonotic, after the discovery of human clinical cases in India and Egypt $[9,10]$. In this paper, we report the first case of surra in North Africa in a Tunisian dog. 


\section{Materials and methods}

\section{Case report}

A two-year-old female Pit-bull dog, living in a tourist leisure centre with 25 dromedaries in the region of Sousse (Central Tunisia) presented a history of chronic ocular symptoms, hyporexia and emaciation. Leishmaniasis was suspected and both lymph node and blood smears were Giemsa stained and examined under a microscope at $\times 1000$ magnification with immersion oil.

\section{Genetic analyses}

The DNA was extracted from the blood sample using a Genomic DNA Purification Kit (Promega, Madison, USA). Trypanosoma evansi PCR was performed with a set of primers that amplifies a $480 \mathrm{bp}$ region of $T$. evansi ITS1 rDNA gene [12]. The forward primer was ITS1 CF (5'-CCGGAAGTTCACCGATATTG- ${ }^{\prime}$ ) and the reverse primer was ITS1 BR (5'-TGCTGCGTTCTTCAACGAA-3'). The PCR mixture consisted of $2.5 \mu \mathrm{L}$ of $10 \times$ PCR buffer (50 mM Tris- $\mathrm{HCl} ; \mathrm{pH} 8.5 ; 50 \mathrm{mM} \mathrm{NaCl}$ ), $2 \mathrm{mM} \mathrm{MgCl}_{2}$, $0.2 \mathrm{mM}$ of each dNTP, $0.2 \mu \mathrm{M}$ of each primer, $0.5 \mathrm{U}$ Taq Polymerase (Vivantis, Chino, California), $3 \mu \mathrm{L}$ of DNA template and distilled water to a total volume of $25 \mu \mathrm{L}$. The DNA was amplified using the following programme: 5 min denaturation at $94{ }^{\circ} \mathrm{C}$, followed by 35 cycles $\left(94{ }^{\circ} \mathrm{C}\right.$ for $40 \mathrm{~s}, 58^{\circ} \mathrm{C}$ for $40 \mathrm{~s}$ and $72{ }^{\circ} \mathrm{C}$ for $90 \mathrm{~s}$ ) and a final extension at $72{ }^{\circ} \mathrm{C}$ for $5 \mathrm{~min}$. The PCR product was purified with the Wizard SV Gel and PCR Clean-Up System (Promega, Madison, USA) according to the manufacturer's instructions. The fragment was sequenced in both directions, using the same primers as for PCR. A conventional BigDye Terminator Cycle Sequencing Ready Reaction Kit (Applied Biosystems, Foster City, CA) and an ABI3730XL automated DNA sequencer were used. The chromatograms were evaluated with ChromasPro software (version 1.7.4). The MEGA 5.1 software program was used to perform multiple sequence alignments [17]. The sequences were compared with the GenBank database by nucleotide sequence homology. Searches were made at the network server of the National Center for Biotechnology Information (NCBI) using BLAST.

\section{Results}

The clinical examination showed significant muscular emaciation and bilateral keratitis with corneal opacity and impaired eyesight (Fig. 1). The lymph nodes were not enlarged but, due to the high prevalence of canine leishmaniasis [2] and babesiosis [11] in Tunisia, a blood smear and a lymph node biopsy were performed, they were negative for Babesia spp. and Leishmania infantum but showed high population of Trypanosoma spp. (Fig. 2). The dog presented hypoglycaemia $(0.76 \mathrm{~g} / \mathrm{L})$, uraemia $(0.9 \mathrm{~g} / \mathrm{L})$, hyperproteinaemia $(84 \mathrm{~g} / \mathrm{L})$ and normocytic $(71.7 \mathrm{fl})$ normochromic $(31.6 \mathrm{~g} / \mathrm{dL})$ regenerative anaemia $(6.8 \mathrm{~g} / \mathrm{dL})$ with severe thrombocytopenia $\left(5 \times 10^{3} / \mu \mathrm{L}\right)$ (Table 1).

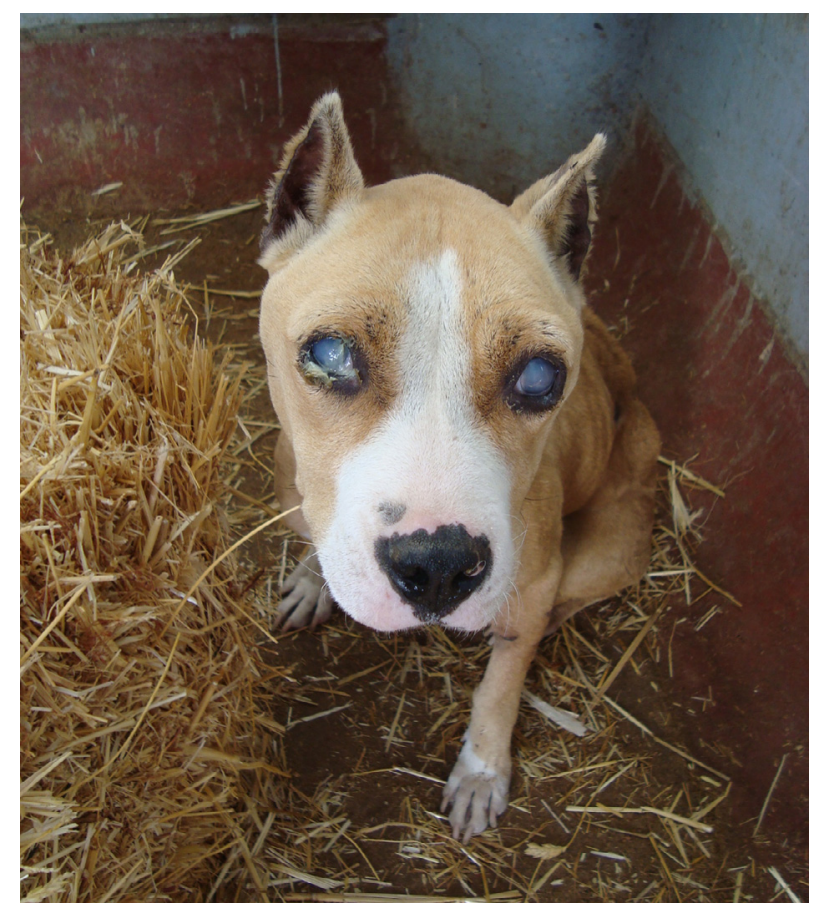

Figure 1. Bilateral purulent blue keratitis in a dog, with surra.

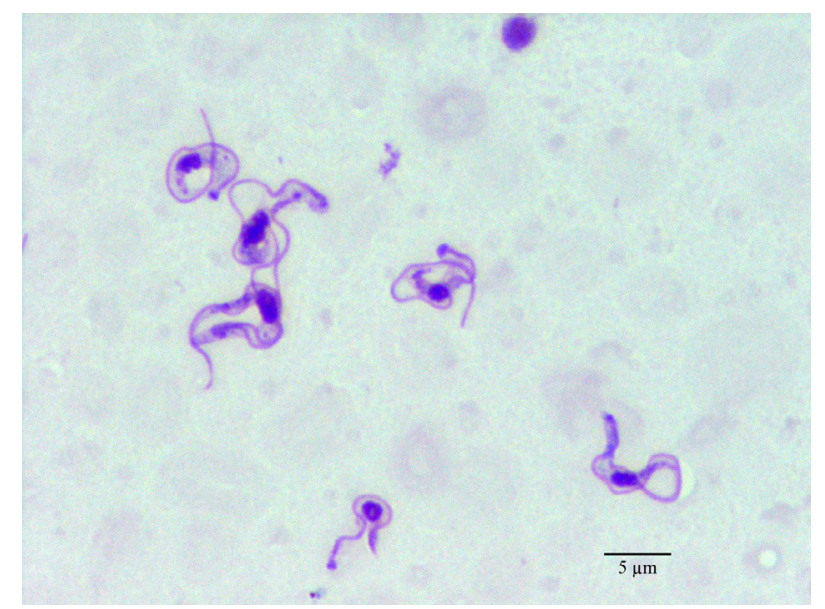

Figure 2. Trypanosoma evansi, dog, Giemsa-stained blood smear.

The dog was treated with intramuscular diminazene aceturate at the conventional dose of $5 \mathrm{mg} / \mathrm{kg}$ but died 2 weeks later. The necropsy revealed cachexia, severe anaemia, subcutaneous oedema, acute interstitial hepatitis and nephritis. The dog also presented congestive inconspicuous generalized adenitis, gastroenteritis with congestive colitis, bilateral mucopurulent conjunctivitis and significant splenomegaly with hyperplasia of the red pulp.

A novel T. evansi ITS1 rDNA genotype named TETND01 (GenBank Accession Number KJ741365) was identified in this study.

The BLAST comparison of the partial sequences of the ITS1 rDNA gene revealed 99.8\% homology between our isolate (KJ741365) and isolates from cattle (AY912277) in Thailand, 99.5\% homology with isolates from dromedaries 
Table 1. Results of biochemical and haematological analyses of the dog infected with Trypanosoma evansi.

\begin{tabular}{lcc}
\hline & $\begin{array}{c}\text { Subject's } \\
\text { values }\end{array}$ & $\begin{array}{c}\text { Reference } \\
\text { values }\end{array}$ \\
\hline Biochemical results & & \\
Glycaemia $(\mathrm{g} / \mathrm{L})$ & 0.76 & $0.6-1.2$ \\
Urea $(\mathrm{g} / \mathrm{L})$ & 0.9 & $0.2-0.5$ \\
Creatininaemia $(\mathrm{mg} / \mathrm{L})$ & 8.0 & $10-20$ \\
ALT $(\mathrm{U} / \mathrm{L})$ & 68.0 & $21-102$ \\
AST $(\mathrm{U} / \mathrm{L})$ & 69.0 & $23-66$ \\
GGT $(\mathrm{U} / \mathrm{L})$ & $<4$ & $<10$ \\
Total Protein $(\mathrm{g} / \mathrm{L})$ & 84.0 & $54-71$ \\
Haematological results & & \\
Leucocytes $\left(10^{9} / \mathrm{L}\right)$ & 9.41 & $6-17$ \\
Erythrocytes $\left(10^{12} / \mathrm{L}\right)$ & 3 & $5.5-8.5$ \\
Corpuscular haemoglobin $(\mathrm{g} / \mathrm{dL})$ & 6.8 & $12-18$ \\
Haematocrit $(\%)$ & 21.5 & $37-55$ \\
Mean corpuscular volume $(\mathrm{fl})$ & 71.7 & $60-77$ \\
Mean corpuscular haemoglobin & 22.7 & $19.5-24.5$ \\
$\quad$ levels $(\mathrm{pg})$ & & \\
Mean corpuscular haemoglobin & 31.6 & $32-36$ \\
$\quad$ concentration $(\mathrm{g} / \mathrm{dL})$ & & \\
Platelets $\left(10^{9} / \mathrm{L}\right)$ & 5 & $200-500$ \\
IDR SV (fl) & 42.6 & $26.3-38.5$ \\
IDR CV $(\%)$ & 16.9 & $9.2-12$ \\
Monocytes $\left(10^{9} / \mathrm{L}\right)$ & 0.66 & $0.15-1.35$ \\
Eosinophils $\left(10^{9} / \mathrm{L}\right)$ & 0 & $0.1-1.25$ \\
Basophils $\left(10^{9} / \mathrm{L}\right)$ & 0.01 & Rare \\
\hline
\end{tabular}

(AB551922) from Egypt and from Thai deer (AY912279), $99.1 \%$ homology with isolates from Thai buffalo (AY912270) and from Chinese mules (FJ712712).

\section{Discussion}

Trypanosomiasis is a common protozoan infection in camels in Tunisia; its seroprevalence was estimated to be $18 \%$ by Gallo et al. in 1989 [7]. Trypanosoma evansi is reported in North Africa, Southern Europe, Latin America and Asia [13]. It is commonly pathogenic in camels, horses, cattle and occasionally in humans [9, 10] and dogs [5]. In humans, innate immunity against $T$. evansi could depend on a plasmatic trypanolytic factor, namely apolipoprotein L-1. Indeed, a deficit in both apolipoprotein L-1 alleles has been discovered in an Indian patient infected by T. evansi [19]. T. evansi in dogs is not frequent; two cases have been reported: one in Germany [3] and another in Afghanistan [1]. Lethargy, weight loss and ocular lesions seem to be constant symptoms in canine surra $[1,3]$. Unlike Aref et al. in 2013 [1], we observe neither diarrhoea nor cardiac disease in the present case. Moreover, Aref et al. did not report any haematological changes since they found normal cell packed volumes and total white cell values. The contamination could occur either orally (by ingestion of aborted placenta or foetuses eliminated by infected females) or by several haematophagous vector species.

Veterinarians in non-endemic regions such as Europe should consider this disease in dogs with a history of living in endemic countries such as Tunisia and presenting weight loss and ocular involvement. The differential diagnosis should be established with canine leishmaniasis (including atypical forms with no obvious lymph node enlargement) and babesiosis. Further studies are needed to estimate the prevalence of different $T$. evansi infection forms (carrier or clinical forms) in Tunisian dogs.

Acknowledgements. The study was supported financially by the "Laboratoire d'épidémiologie des infections enzootiques des herbivores en Tunisie" (Ministère de l'enseignement supérieur, de la recherche scientifique, de la technologie et de la communication, Tunisia). The authors thank Dr Moez Mhadhbi, Mr Bechir Guesmi and Mr Mohamed Jedidi for their support.

\section{References}

1. Aref M, Yasin SM, Bahear W, Ghulam Z, Hastie L, Dennison T, Schauwers W, Büscher P, Deborggraeve S. 2013. Canine Trypanosoma evansi infection in Afghanistan. Veterinary Parasitology, 197, 638-641.

2. Bouratbine A, Aoun K, Gharbi M, Haouas N, Zaroui J, Harrat Z, Baba H, Darghouth MA. 2005. Données épidémiologiques, cliniques et parasitologiques sur la leishmaniose générale canine en Tunisie. Bulletin de la Société de Pathologie Exotique, 98, 359-362.

3. Defontis M, Richartz J, Engelmann N, Bauer C, Schwierk VM, Büscher P, Moritz A. 2012. Canine Trypanosoma evansi infection introduced into Germany. Veterinary Clinical Pathology, 41, 369-374.

4. Desquesnes M, Bossard G, Patrel D, Herder S, Patout O, Lepetitcolin E, Thevenon S, Berthier D, Pavlovic D, Brugidou R, Jacquiet P, Schelcher F, Faye B, Touratier L, Cuny G. 2008. First outbreak of Trypanosoma evansi in camels in metropolitan France. Veterinary Record, 162, 750-752.

5. Desquesnes M, Holzmuller P, Lai D-H, Dargantes A, Lun Z-R, Jittaplapong S. 2013. Trypanosoma evansi and surra: a review and perspectives on origin, history, distribution, taxonomy, morphology, hosts, and pathogenic effects. BioMed Research International, 2013, 194176.

6. Dia ML, Desquesnes M. 2007. Infections expérimentales de bovins par Trypanosoma evansi: pathogénicité et efficacité du traitement au Cymelarsan. Revue Africaine de Santé et de Productions Animales, 5, 37-41.

7. Gallo C, Vesco G, Campo F, Hadad N, Abelmoula H. 1989. Enquête zoosanitaire chez les chèvres et les dromadaires au sud de la Tunisie. Maghreb Vétérinaire, 17, 15-17.

8. Gutierrez C, Montoya JA, Padron M, Corbera JA, Juste MC, Molina JM. 1998. Descripcion de un caso de tripanosomiasis en el dromedario por $T$. evansi en Canarias. Medicina Veterinaria, 15, 356-357.

9. Haridy FM, El-Metwally MT, Khalil HH, Morsy TA. 2011. Trypanosoma evansi in dromedary camel: with a case report of zoonosis in greater Cairo, Egypt. Journal of the Egyptian Society of Parasitology, 41, 65-76.

10. Joshi PP, Shegokar VR, Powar RM, Herder S, Katti R, Salkar HR, Dani VS, Bhargava A, Jannin J, Truc P. 2005. Human trypanosomiasis caused by Trypanosoma evansi in India: the first case report. American Journal of Tropical Medicine and Hygiene, 73, 491-495.

11. M'ghirbi Y, Bouattour A. 2008. Detection and molecular characterization of Babesia canis vogeli from naturally infected dogs and Rhipicephalus sanguineus ticks in Tunisia. Veterinary Parasitology, 152, 1-7. 
12. Njiru ZK, Constantine CC, Guya S, Crowther J, Kiragu JM, Thompson RC, Davila AM. 2005. The use of ITS1 rDNA PCR in detecting pathogenic African trypanosomes. Parasitology Research, 95, 186-192.

13. OIE, 2008. Manual of Diagnostic Tests and Vaccines for Terrestrial Animals. Online: www.oie.int

14. Reduth D, Grootenhuis JG, Olubayo RO, Muranjan M, OtienoOmondi FP, Morgan GA, Brun R, Williams DJL, Black SJ. 1994. African buffalo serum contains novel trypanocidal protein. Journal of Eukaryotic Microbiology, 41, 95-103.

15. Salim B, Bakheit MA, Kamau J, Nakamural I, Sugimoto C. 2011. Molecular epidemiology of camel trypanosomiasis based on ITS1 rDNA and RoTat 1.2 VSG gene in the Sudan. Parasites and Vectors, 4, 31.
16. Tamarit A, Gutierrez C, Arroyo R, Jimenez V, Zagalá G, Bosch I, Sirvent J, Alberola J, Alonso I, Caballero C. 2010. Trypanosoma evansi infection in mainland Spain. Veterinary Parasitology, 167, 74-76.

17. Tamura K, Peterson D, Peterson N, Stecher G, Nei M, Kumar S. 2011. MEGA5: molecular evolutionary genetics analysis using maximum likelihood, evolutionary distance, and maximum parsimony methods. Molecular Biology and Evolution, 28, 2731-2739.

18. Tarello W. 2005. Trypanosoma evansi infection in three cats. Revue de Médecine Vétérinaire, 156, 133-134.

19. Truc P, Nzoumbou-Boko R, Desquesnes M, Semballa S, Vincendeau P. 2014. Atypical human trypanosomoses. Médecine et Santé Tropicales, 24, 249-252.

Cite this article as: Rjeibi MR, Ben Hamida T, Dalgatova Z, Mahjoub T, Rejeb A, Dridi W \& Gharbi M: First report of surra (Trypanosoma evansi infection) in a Tunisian dog. Parasite, 2015, 22, 3.

\section{PARASTTE}

An international open-access, peer-reviewed, online journal publishing high quality papers on all aspects of human and animal parasitology

Reviews, articles and short notes may be submitted. Fields include, but are not limited to: general, medical and veterinary parasitology; morphology, including ultrastructure; parasite systematics, including entomology, acarology, helminthology and protistology, and molecular analyses; molecular biology and biochemistry; immunology of parasitic diseases; host-parasite relationships; ecology and life history of parasites; epidemiology; therapeutics; new diagnostic tools.

All papers in Parasite are published in English. Manuscripts should have a broad interest and must not have been published or submitted elsewhere. No limit is imposed on the length of manuscripts.

Parasite (open-access) continues Parasite (print and online editions, 1994-2012) and Annales de Parasitologie Humaine et Comparée (1923-1993) and is the official journal of the Société Française de Parasitologie.
Submit your manuscript at http://parasite.edmgr.com/ 